\title{
Investigating the effect of clicker use on problem-solving among adult learners: A cross-sectional survey
}

\author{
Haifa Fahad Bin Mubayrik*
}

doi: http://dx.doi.org/10.18543/tjhe-7(2)-2020pp141-158

Received: 26 September 2019

Accepted: 4 March 2020

\begin{abstract}
Classroom response systems (clickers) have been found to engage and attract student attention and facilitate the practical application of key ideas to solve problems. This study was designed to investigate the effects of clicker use on problem-solving among adult learners. A self-administered questionnaire was distributed to 60 students after giving them actual case studies for problem-solving using PowerPoint slides. An equal number of participants were assigned to each of the control $(n=30)$ and experimental groups $(n=30)$. Although both groups engaged in the same problem-solving tasks, the experimental group used clickers as a learning tool in the classroom. Data were analyzed using frequency, means, exploratory factor analysis, the Friedman ranking test, and linear regression analysis. The study findings revealed overall positive responses toward using clickers in the classroom. They also suggested that clickers encouraged thinking and problem-solving. It is concluded that problem-solving learning in adult education appears to be more effective when accompanied by clicker use than through conventional teaching methods.
\end{abstract}

Keywords: Clickers; adult education; problem-solving; adult learning; instructional design.

* Haifa F. Bin Mubayrik (halmobeeriek@ksu.edu.sa), PhD in Foundation of Education, is Associate Professor at the Department of Educational policies, College of Education, King Saud University, Riyadh, Saudi Arabia.

More information about the author is available at the end of this article.

Acknowledgements: The author would like to express deepest thanks to the Researchers Support and Services Unit at King Saud University for their editorial assistance.

Funding: This research project was supported by a grant from the Research Center for Humanities, Deanship of Scientific Research, King Saud University, Riyadh, Saudi Arabia.

Conflict of interest: The author declares no conflict of interest.

Ethical approval: Ethical approval was obtained from Research Ethics Committee, Deanship of Scientific Research, King Saud University (KSU-HE-19-234). 


\section{Background}

Educators worldwide strive for effective, lifelong learning, both inside and outside the classroom. Several classroom strategies have been utilized in an attempt to achieve this goal. Inquiry-based learning (IBL) and problemsolving learning are student-centered teaching strategies that involve presenting a challenge to the student to accomplish the desired learning. ${ }^{1}$ Classroom response systems (clickers) technology has been reported to engage and attract student attention and encourage the practical application of key ideas to problem-solving. ${ }^{2}$ One area where the practical application of this technology is an important issue is healthcare, particularly for clinical reasoning, decision-making, and providing opportunities for comments and debates to enhance learning and future application. ${ }^{3}$ Use of technology and practice-oriented problem-solving promotes the development of clinical skills and the ability for future adaptation. ${ }^{4}$ It has been reported that using clickers in the classroom has a positive impact on learning, class engagement, understanding, retention, self-control, self-efficacy, and enjoyability. ${ }^{5}$

Further, clickers are good tools for providing personalized anonymous feedback, which is a vital part of any teaching modality. In addition, they have been shown to be an effective tool for monitoring learning. ${ }^{6}$ All of these

${ }^{1}$ Michael J. Prince and Richard M. Felder, "Inductive Teaching and Learning Methods: Definitions, Comparisons, and Research Bases," Journal of Engineering Education 95, no. 2 (2006): 123-138.

2 Ashley Deal, "Classroom Response Systems," published November 30, 2007, https:// www.cmu.edu/teaching/technology/whitepapers/ClassroomResponse_Nov07.pdf, accessed 8/4/2019.

${ }^{3}$ Hyunjung Ju and Ikseon Choi, "The Role of Argumentation in Hypothetico-Deductive Reasoning During Problem-Based Learning in Medical Education: A Conceptual Framework," Interdisciplinary Journal of Problem-Based Learning 12, no. 1 (2018): 100-116.

${ }^{4}$ Nadiia Demikhova et al., "Using PBL and Interactive Methods in Teaching Subjects in Medical Education," Journal of Problem Based Learning in Higher Education 4, no. 1 (2016): $81-90$.

5 Jae Hoon Han and Adam Finkelstein, "Understanding the Effects of Professors' Pedagogical Development with Clicker Assessment and Feedback Technologies and the Impact on Students' Engagement and Learning in Higher Education," Computers \& Education 65 (2013): 64-76; Maite Millor et al., "Use of Remote Response Devices: An Effective Interactive Method in the Long-Term Learning," European Radiology 25, no. 3 (2015): 894900; Isabel Buil, Sara Catalán, and Eva Martínez, "Do Clickers Enhance Learning? A ControlValue Theory Approach," Computers \& Education 103 (2016): 170-182; and Niall T. Stevens, et al., "A Comparative Study: Do "Clickers" Increase Student Engagement in Multidisciplinary Clinical Microbiology Teaching?" BMC Medical Education 17, no. 1 (2017): 1-8.

${ }^{6}$ Han and Finkelstein, "Understanding the Effects." 
advantages have a positive effect by increasing pride, learning, satisfaction, and intrinsic and extrinsic motivation, decreasing boredom, and providing the desire for continuous education. ${ }^{7}$ Problem-solving aided by welldesigned multiple-choice questions has been found to enhance cognitive abilities because it requires the execution of processes to solve complex problems, thus assisting in facing real-world situations with confidence. ${ }^{8}$ Clicker use has been shown to assist students who are not able to solve problems through discussions or anonymous trial and error. ${ }^{9}$ Both educational policymakers and educators are constantly looking for strategies to support beneficial and enjoyable lifelong learning. This is particularly true for medical education where individuals are placed in situations that require problem-solving and decision-making throughout their careers. This study was designed to investigate problem-solving assisted by classroom response systems (clickers) among adult learners. The study attempted to answer the following research questions: Are there any differences between learning with and learning without clickers? Does using clickers encourage thinking and problem-solving? Do clickers support interactive learning and peer discussion?

\section{Methods}

Ethical approval was granted by the local institutional Research Ethics Committee. A semi-structured, self-administered questionnaire was developed on the basis of the literature,$^{10}$ which contains questions about clickers facilitating problem-solving, thinking, interactive learning, and selfassessment. The questionnaire used a 5-point Likert scale with responses

${ }^{7}$ Isabel Buil, Sara Catalán, and Eva Martínez, "Do Clickers Enhance Learning?”; and Unal Cakiroglu, Fath Erdogdu, and Seyfullah Gokoglu, "Clickers in EFL Classrooms: Evidence from Two Different Uses," Contemporary Educational Technology 9, no. 2 (2018): $171-185$.

${ }^{8}$ Sylvain P. Coderre et al., "The Impact of Two Multiple-Choice Question Formats on the Problem-Solving Strategies Used by Novices and Experts," BMC Medical Education 4, no. 1 (2004): 23.

9 Aime A. Levesque, "Using Clickers to Facilitate Development of Problem-Solving Skills," CBE-Life Sciences Education 10, no. 4 (2011): 406-417.

10 Janet S. Russell et al., "Using Clickers for Clinical Reasoning and Problem Solving," Nurse Educator 36, no. 1 (2011): 13-15; and Elio F. Spinello and Ronald Fischbach, "Using a Web-Based Simulation as a Problem-Based Learning Experience: Perceived and Actual Performance of Undergraduate Public Health Students," Public Health Reports 123, no. 2 (2008): 78-84. 
ranging from strongly agree to strongly disagree. To assess reliability, the questionnaire was pretested on 30 adult students. No adjustments were necessary, and the questionnaire was distributed among the study population. Participation was voluntary. The inclusion criterion was being an adult student attending clinics and exposed to problem-solving teaching techniques without using clickers. The exclusion criteria were refusal to participate in the study and lack of problem-solving experience. The questionnaires were distributed to senior students, the purpose of the study was explained, all questions were resolved prior to participation, and informed consent was obtained.

The study sample consisted of 60 students distributed equally into two groups; one group was assigned to problem-solving with clicker use, and the second group was taught by following the traditional method (problemsolving without clickers). In both groups, students were presented with actual case studies using PowerPoint slides and were encouraged to engage in problem-solving through clinical debate. In the experimental group, students were asked to respond to multiple-choice questions using the clicker. The students' responses were then displayed in a bar graph and students were invited to provide peer opinions, discussions, and perspectives on the responses. The correct answer was then displayed. For the control group, the same PowerPoint slides were used to encourage problem-solving through clinical debate. They were then asked to respond to the same multiple-choice questions without clicker use and invited to provide opinions and engage in a discussion.

\section{II.1. Statistical analysis}

The collected data were analyzed using SPSS Version 22 (IBM Corp. Released 2013. IBM SPSS Statistics for Windows, Version 22.0. Armonk, NY: IBM Corp). Frequency, means, factor analysis, the Friedman ranking test, and simple linear regression were used to analyze the data.

\section{Results}

\section{III.1. The psychometric characteristics of the questionnaire}

Psychometric characteristics were assessed using validity and reliability of the questionnaire. 


\section{III.1.1. Questionnaire validity}

\section{III.1.1.1. Factor analysis}

Factor analysis was performed (Table 1). The correlation matrix showed the appropriateness of the data for factor analysis. The Kaiser-Meyer-Olkin measure of sampling adequacy was 0.834 (more than 0.6). Bartlett's test of sphericity was significant $(0.0001)$; thus, a factor analysis with principal component analysis was performed. Using the rotated component matrix and the extraction method with Varimax rotation and Kaiser normalization, three factors were extracted. The names of the factors were created on the basis of the meaning of the variables included in each factor. These three factors were 1) support interactive learning, 2) encourage thinking and problem-solving, and 3) self-assessment.

Table 1

Factor Loadings of Questionnaire Items Regarding Clicker Use

\begin{tabular}{|c|c|c|c|c|}
\hline \multirow{2}{*}{ No. } & \multirow{2}{*}{ Statement } & \multicolumn{3}{|c|}{ Component } \\
\hline & & 1 & 2 & 3 \\
\hline Q8 & $\begin{array}{l}\text { I felt that my opinions have been taken into } \\
\text { account }\end{array}$ & .915 & & \\
\hline Q7 & $\begin{array}{l}\text { Using the clickers helped me to participate in } \\
\text { problem-solving more openly }\end{array}$ & .868 & & \\
\hline Q9 & Helped in evaluating student understanding & .862 & & \\
\hline Q3 & $\begin{array}{l}\text { Clickers helped me understand and comprehend } \\
\text { the clinical problems }\end{array}$ & .859 & & \\
\hline Q14 & Helps prepare me for a future career & .840 & & \\
\hline Q2 & $\begin{array}{l}\text { Clickers made the problem-solving more } \\
\text { interesting }\end{array}$ & .836 & & \\
\hline Q12 & $\begin{array}{l}\text { Improved critical thinking and helped build } \\
\text { knowledge }\end{array}$ & .831 & & \\
\hline Q10 & It helped me in making clinical decisions & .802 & & \\
\hline Q5 & $\begin{array}{l}\text { Immediate feedback from instructor helped my } \\
\text { understanding }\end{array}$ & .794 & & \\
\hline Q11 & Has led to a better learning experience in this field & .790 & & \\
\hline
\end{tabular}


......

\begin{tabular}{|c|l|c|c|c|}
\hline \multirow{2}{*}{ No. } & \multicolumn{1}{|c|}{ Statement } & \multicolumn{3}{|c|}{ Component } \\
\cline { 3 - 5 } Q4 & $\begin{array}{l}\text { Clickers encourage students to answer and solve } \\
\text { problems }\end{array}$ & .644 & 2 & 3 \\
\hline Q1 & The use of clickers encourages thinking skills & & .636 & \\
\hline Q13 & $\begin{array}{l}\text { Helped interaction and solving issues of scientific } \\
\text { debate and confusion }\end{array}$ & & .786 & .476 \\
\hline Q15 & $\begin{array}{l}\text { Enhanced my ability to actively solve real-life } \\
\text { problems }\end{array}$ & & & .924 \\
\hline Q16 & $\begin{array}{l}\text { Distribution of class responses helped me be } \\
\text { aware of my strengths and weaknesses }\end{array}$ & & & \\
\hline
\end{tabular}

\section{III.1.2. Reliability}

Cronbach's Alpha was 0.917. Table 2 shows Cronbach's $\alpha$ values, which were above 0.70 for the questionnaire items, indicating a good internal consistency. It ranged from 0.905 for "clickers made the problem-solving more interesting" to 0.932 for "distribution of class responses helps to know my strength and weakness." Item-total correlation coefficients were positive and above 0.20 (Pearson's $r>0.2$ ) for including the item.

Table 2

Reliability Analysis Based on the Corrected Item-total Correlation and Cronbach's Alpha Coefficient if Item Deleted

\begin{tabular}{|c|l|c|c|}
\hline No. & \multicolumn{1}{|c|}{ Impact Item } & $\begin{array}{c}\text { Corrected } \\
\text { Item- } \\
\text { Total } \\
\text { Correlation }\end{array}$ & $\begin{array}{c}\text { Cronbach's } \\
\text { Alpha if Item } \\
\text { Deleted }\end{array}$ \\
\hline 1. & $\begin{array}{l}\text { The use of clickers encouraged thinking } \\
\text { skills }\end{array}$ & .533 & .915 \\
\hline 2. & $\begin{array}{l}\text { Clickers made the problem-solving more } \\
\text { interesting }\end{array}$ & .854 & .905 \\
\hline 3. & $\begin{array}{l}\text { Clickers helped me understand and } \\
\text { comprehend the clinical problems }\end{array}$ & .797 & .906 \\
\hline
\end{tabular}




\begin{tabular}{|c|c|c|c|}
\hline No. & Impact Item & $\begin{array}{l}\text { Corrected } \\
\text { Item- } \\
\text { Total } \\
\text { Correlation }\end{array}$ & $\begin{array}{l}\text { Cronbach's } \\
\text { Alpha if Item } \\
\text { Deleted }\end{array}$ \\
\hline 4. & $\begin{array}{l}\text { Clickers encourage students to answer } \\
\text { and solve problems }\end{array}$ & .794 & .909 \\
\hline 5. & $\begin{array}{l}\text { Immediate feedback from instructor } \\
\text { helped me to understand }\end{array}$ & .816 & .907 \\
\hline 6. & $\begin{array}{l}\text { Discussions with peers help me to better } \\
\text { understand the course material }\end{array}$ & .803 & .909 \\
\hline 7. & $\begin{array}{l}\text { Using the clickers helped me participate } \\
\text { in problem-solving more openly }\end{array}$ & .811 & .906 \\
\hline 8. & $\begin{array}{l}\text { I felt that my opinions have been taken } \\
\text { into account }\end{array}$ & .859 & .905 \\
\hline 9. & $\begin{array}{l}\text { Helped in evaluating student } \\
\text { understanding }\end{array}$ & .745 & .908 \\
\hline 10. & It helped me in making clinical decisions & .732 & .909 \\
\hline 11. & $\begin{array}{l}\text { Has led to a better learning experience } \\
\text { in this field }\end{array}$ & .782 & .908 \\
\hline 12. & $\begin{array}{l}\text { Improved critical thinking and helped } \\
\text { build knowledge }\end{array}$ & .860 & .906 \\
\hline 13. & $\begin{array}{l}\text { Helped interaction and solving issues of } \\
\text { scientific debate and confusion }\end{array}$ & .749 & .910 \\
\hline 14. & Helps prepare me for a future career & .721 & .909 \\
\hline 15. & $\begin{array}{l}\text { Enhanced my ability to actively solve } \\
\text { problems in the real life }\end{array}$ & .030 & .929 \\
\hline 16. & $\begin{array}{l}\text { Distribution of class responses helps } \\
\text { me learn about my strengths and } \\
\text { weaknesses }\end{array}$ & -.016 & .932 \\
\hline
\end{tabular}

\section{III.2. Results of the pretest}

A pretest (problem-solving without clickers) was conducted to assess whether there were statistically significant differences between experimental and control groups before clicker use. The researcher used the t-test to detect the significance of the differences between the average scores of the 
experimental and control groups at the level $\mathrm{p} \leq 0.05$ in the pretest before clicker use was introduced (Table 3 ). Table 3 shows that there was no statistically significant difference between the mean scores of the experimental and control groups before clicker use. The mean scores of the experimental and control groups in the pretest are represented graphically in Figure 1.

\section{Table 3}

Means, Standard Deviations, Value of T, Level of Significance, and Value of Impact Between the Means of the Experimental and Control Groups in the Pretest

\begin{tabular}{|c|l|c|c|c|c|c|c|c|}
\hline Variable & \multicolumn{1}{|c|}{ Group } & $\mathrm{N}$ & Mean & $\begin{array}{c}\text { Std. } \\
\text { Deviation }\end{array}$ & $\mathrm{df}$ & $\mathrm{T}$ & $\begin{array}{c}\text { Sig. } \\
\text { (2-tailed) }\end{array}$ & $\begin{array}{c}\text { effect } \\
\text { size }\end{array}$ \\
\hline Questionnaires & Control & 30 & 24.4511 & 2.3669 & 58 & 1.458 & $\begin{array}{l}\text { Not } \\
\text { Significant }\end{array}$ & 0.03 \\
\cline { 2 - 5 } & Experimental & 30 & 23.4364 & 2.9856 & & & & small \\
\hline
\end{tabular}

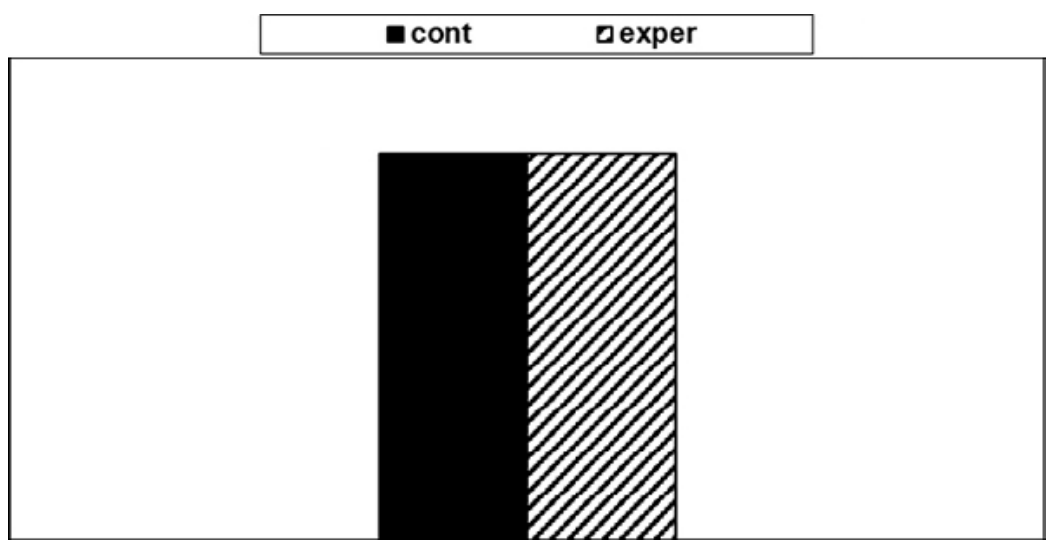

Figure 1

Graphical Representation of the Pretest Mean Score of the Questionnaire before Clicker Use

III.3. Results of the post-test

A t-test was conducted to test the validity of the following hypothesis: There will be a statistically significant difference at the level of $p \leq 0.05$ 
between the means of the control and experimental group in the post-test. The researcher used a t-test to detect differences between the mean scores of the experimental and control groups following the introduction of clicker use for the experimental group (Table 4). Table 4 shows that there was a statistically significant difference between the mean scores of the control and experimental groups following the introduction of clicker use in the experimental group. So, the size of the effect of the independent variable on the dependent variable was found to be strong. The mean scores for the experimental and control groups are represented graphically in Figure 2.

\section{Table 4}

Means, Standard Deviations, Value of T, Level of Significance, and Value of Impact Between the Means of the Experimental and Control Groups in the Posttest

\begin{tabular}{|c|l|c|c|c|c|c|c|c|}
\hline Variable & \multicolumn{1}{|c|}{ Group } & $\mathrm{N}$ & Mean & $\begin{array}{c}\text { Std. } \\
\text { Deviation }\end{array}$ & $\mathrm{df}$ & $\mathrm{T}$ & $\begin{array}{c}\text { Sig. } \\
\text { (2-tailed) }\end{array}$ & $\begin{array}{c}\text { effect } \\
\text { size }\end{array}$ \\
\cline { 1 - 9 } Questionnaires & Control & 30 & 32.3871 & 1.0962 & 58 & 24.055 & 0.01 & 0.89 \\
\cline { 2 - 5 } & Experimental & 30 & 52.523 & 4.4521 & & & & large \\
\hline
\end{tabular}

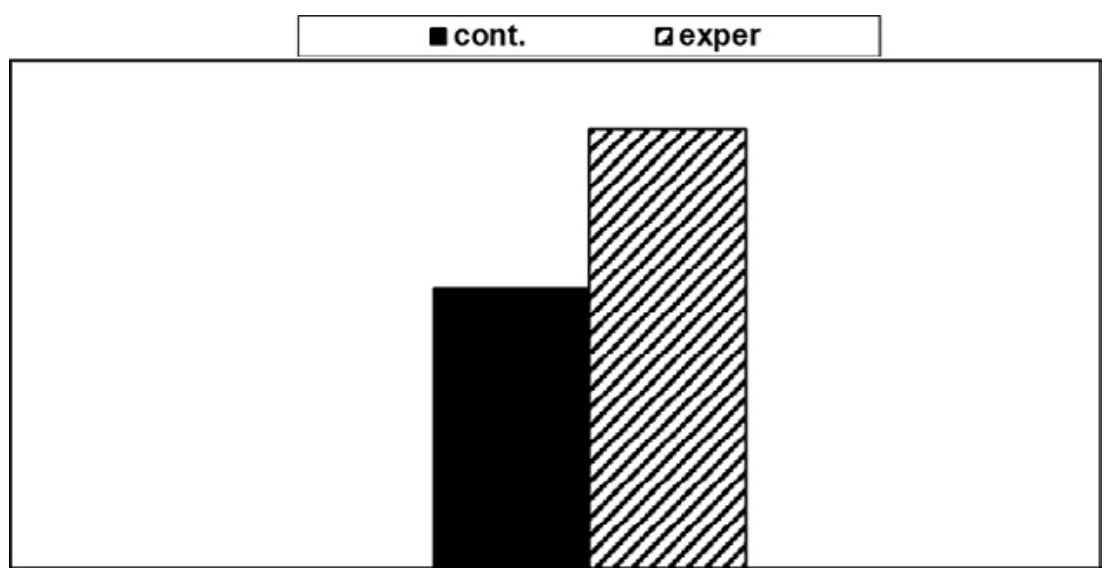

Figure 2

Graphical Representation of the Post-test Mean Score for the Experimental and Control Groups Following Introduction of Clicker Use in the

Experimental Group 


\section{III.4. Friedman ranking test}

Using the Friedman ranking test, self-assessment was ranked by the experimental group as the most significant benefit, followed by encouraging thinking and problem-solving, and supporting interactive learning $(\mathrm{p}=$ 0.0001) (Table 5).

When comparing different items among the experimental group; factor \#1 (use of clickers encouraged thinking skills) was ranked first (10.46), whereas item \#14 (helps prepare me for a future career) was ranked as the least significant advantage (Table 6).

Table 5

Factors Ranked by Students' Responses

\begin{tabular}{|l|c|}
\hline \multicolumn{1}{|c|}{ Variable } & Mean Rank \\
\hline Self-assessment & 2.20 \\
\hline Encouraging thinking and problem-solving & 2.12 \\
\hline Support interactive learning & 1.68 \\
\hline $\mathrm{N}$ & 117 \\
\hline Chi-Square & 22.407 \\
\hline Df & 2 \\
\hline Asymp. Sig. & .000 \\
\hline
\end{tabular}

Table 6

Different Factors as Ranked by the Respondents

\begin{tabular}{|c|l|c|}
\hline No & \multicolumn{1}{|c|}{ Factor } & $\begin{array}{c}\text { Mean } \\
\text { Rank }\end{array}$ \\
\hline Q1 & The use of clickers encouraged thinking skills & 10.46 \\
\hline Q4 & Clickers encouraged students to answer and solve problems & 10.32 \\
\hline Q13 & $\begin{array}{l}\text { Helped interaction and solving issues of scientific debate and } \\
\text { confusion }\end{array}$ & 9.59 \\
\hline Q6 & $\begin{array}{l}\text { Discussions with peers help me to better understand the } \\
\text { course material }\end{array}$ & 9.52 \\
\hline Q15 & Enhanced my ability to actively solve problems in the real life & 9.14 \\
\hline Q11 & Has led to a better learning experience in this field & 8.54 \\
\hline
\end{tabular}




\begin{tabular}{|c|c|c|}
\hline No & Factor & $\begin{array}{l}\text { Mean } \\
\text { Rank }\end{array}$ \\
\hline Q12 & Improved critical thinking and helped build knowledge & 8.37 \\
\hline Q7 & $\begin{array}{l}\text { Using the clickers helped me participate in problem-solving } \\
\text { more openly }\end{array}$ & 8.36 \\
\hline Q8 & I felt that my opinions have been taken into account & 8.27 \\
\hline Q2 & Clickers made the problem-solving more interesting & 8.20 \\
\hline Q5 & Immediate feedback from instructor helped me to understand & 7.96 \\
\hline Q16 & $\begin{array}{l}\text { Distribution of class responses helps me learn about my } \\
\text { strengths and weaknesses }\end{array}$ & 8.77 \\
\hline Q9 & Helped in evaluating student understanding & 7.74 \\
\hline Q3 & $\begin{array}{l}\text { Clickers helped me understand and comprehend the clinical } \\
\text { problems }\end{array}$ & 7.07 \\
\hline Q10 & It helped me in making clinical decisions & 7.20 \\
\hline Q14 & Helps prepare me for a future career & 6.49 \\
\hline
\end{tabular}

\section{III.5. Regression}

A linear regression analysis was performed to test whether the support for interactive learning and self-assessment enhances thinking abilities and problem-solving significantly. The Pearson correlation indicated a direct positive relation and that any increase in teaching support would result in a $42.2 \%$ increase in thinking. The ANOVA was significant at $p=.020$. The regression equation was: encouraging, thinking, and problem-solving $=$ $2.643+0.33 *$ support education $(\mathrm{Y}=3.06+0.34 \mathrm{X})$ with a significance level $\mathrm{p}$ $=.000, \mathrm{R} 2=.178, \mathrm{~F}(1,29)=6.080, \mathrm{p}<.000$. It was found that supporting education can significantly predict thinking abilities and problem-solving.

\section{Discussion}

Among educators and education policymakers there are two essential matters: teaching strategies and learning. An influential educational tool for the young generation is technology-aided teaching. Both clickers and problem-solving strategies are beneficial to the process of recalling and 
remembering, and thus information retention, real-world problem-solving, and decision-making. Using actual or practice-based cases allows the application of knowledge and skills development. It has been reported that real-world simulation is an effective method in the healthcare field. ${ }^{11}$

This investigation revealed that using clickers strongly assisted in thinking skills and problem-solving and was ranked first with the highest mean. Cook and Calkins ${ }^{11}$ found that the use of clickers promotes high-order questioning on Bloom's taxonomy, depending on whether the question is designed around analyzing, evaluating, creating, or just recall and remembering.

High order skills and metacognition are reported when clickers are combined with other teaching strategies $.^{12},{ }^{13}$ Morales attributed this to problem-solving learning with the help of a dynamic, relaxing, and engaging atmosphere created by the use of clickers. Moreover, it has been shown that incorporating clickers in any teaching strategy appears to have a positive effect. $^{14}$

In agreement with others $,{ }^{15},{ }^{16}$ this study found that learning was more interesting and thus engaging. Clickers also helped in problem-solving, possibly through stimulation of the students, interaction, and discussion. Furthermore, anonymity allows learning and comprehension of the problem through trial and error. It has been shown that anonymity affects group interaction and learners' participation. When anonymous, learners feel safe to inquire and respond; thus Clickers de-individualizes and reduces social barriers and behavioral restrictions. Students made more comments and

${ }^{11}$ Rifka Cook and Susanna Calkins, "More Than Recall and Opinion: Using "Clickers" to Promote Complex Thinking," Journal on Excellence in College Teaching 24, no. 2 (2019): $51-76$.

${ }^{12}$ Melanie Brady, Helena Seli, and Jane Rosenthal, “'Clickers' and Metacognition: A Quasi-Experimental Comparative Study about Metacognitive Self-Regulation and Use of Electronic Feedback Devices," Computers \& Education 65 (2013): 56-63.

${ }^{13}$ Lucia Morales, "Can the Use of Clickers or Continuous Assessment Motivate Critical Thinking? A Case Study Based on Corporate Finance Students," Higher Learning Research Communications 1, no. 1 (2011): 33.

14 Jae Hoon Han and Adam Finkelstein, "Understanding the Effects of Professors' Pedagogical Development with Clicker Assessment and Feedback Technologies and the Impact on Students' Engagement and Learning in Higher Education," Computers \& Education 65 (2013): 64-76.

${ }^{15}$ Cui Liu et al., "The Effects of Clickers with Different Teaching Strategies," Journal of Educational Computing Research 55, no. 5 (2017): 603-628.

${ }^{16}$ Han and Finkelstein, "Understanding the Effects"; Millor et al., "Use of Remote Response Devices”; Buil, Catalán, and Martínez, "Do Clickers Enhance Learning?”; Stevens et al., "A Comparative Study"; and Liu et al., "The Effects of Clickers." 
practiced critical thinking more than when they are identifiable ${ }^{17},{ }^{18}$ Encouraging students to participate within the context of the clicker-created atmosphere facilitated problem-solving, most likely due to the immediate feedback and self-reflection among students, thus assisting in preparing them for future clinical situations. ${ }^{19}$ In addition, this could assist them in how to find solutions, organize information, and build knowledge.

The results of this investigation showed that, as an instructional method, clickers rely on questioning and peer discussion, thus stimulating the latter and resulting in scientific debates that help build communication skills with teachers and colleagues. ${ }^{20}$ However, questions should be designed to encourage peer discussion that will help them arrive at the correct answers and improve understanding ${ }^{21}{ }^{22},{ }^{23}$ Communication is an essential part of the healthcare profession when dealing with patients, particularly those with serious diseases, as well as in interprofessional collaboration. Communication in healthcare is a vital issue in patient safety and outcomes. ${ }^{24}$

As reported in the literature, the results of this study indicate that immediate feedback was a significant part of using clickers. ${ }^{25}$ It has been

${ }^{17}$ Rifka Cook and Susanna Calkins, "More Than Recall and Opinion: Using "Clickers" to Promote Complex Thinking," Journal on Excellence in College Teaching 24, no. 2 (2019): 51-76.

${ }^{18}$ Leonard M. Jessup, Terry Connolly, and Jolene Galegher, "The Effects of Anonymity on GDSS Group Process with an Idea-Generating Task," MIS Quarterly 14, no. 3 (1990): 313-21. doi: 10.2307/248893.

${ }^{19}$ Levesque, "Using Clickers to Facilitate Development."

${ }^{20}$ Morales, "Can the Use of Clickers"; Nancy Meedzan and Kelly L. Fisher, "Clickers in Nursing Education: An Active Learning Tool in the Classroom," Online Journal of Nursing Informatics (OJNI) 13, no. 2 (2019): 1-19; and Wentao Chen, Jinyu Zhang, and Zhonggen Yu, "Advantages and Disadvantages of Clicker Use in Education," International Journal of Information and Communication Technology Education 13, no. 1 (2017): 61-71.

${ }^{21}$ Wentao Chen, Jinyu Zhang, and Zhonggen Yu, "Advantages and Disadvantages."

${ }^{22}$ Michelle K. Smith et al., "Why Peer Discussion Improves Student Performance on inClass Concept Questions," Science 323, no. 5910 (2009): 122-124.

${ }^{23}$ Michelle K. Smith et al., "Using Peer Discussion Facilitated by Clicker Questions in an Informal Education Setting: Enhancing Farmer Learning of Science," PLoS ONE 7, no. 10 (2012): e47564.

24 Janet Wagner, Beth Liston, and Jackie Miller, "Developing Interprofessional Communication Skills," Teaching and Learning in Nursing 6, no. 3 (2011): 97-101; and Cynthia Foronda, Brent MacWilliams, and Erin McArthur, "Interprofessional Communication in Healthcare: An Integrative Review," Nurse Education in Practice 19 (2016): 36-40.

${ }^{25}$ Melanie Brady, Helena Seli, and Jane Rosenthal, “'Clickers' and Metacognition”; Meedzan and Fisher, "Clickers in Nursing Education"; and Michael E. Lantz and Angela Stawiski, "Effectiveness of Clickers: Effect of Feedback and the Timing of Questions on Learning," Computers in Human Behavior 31 (2014): 280-286. 
reported that feedback is essential for continuous learning and improvement; ${ }^{26}$ it requires skills to deliver and is essential to the quality of learning. ${ }^{27}$ Using clickers can overcome students' fears of being evaluated or judged by teachers or peers. Their use assists in delivering effective and immediate feedback along with a positive learning experience. Clickers can serve as a formative type of assessment to show areas of strength and weakness among students. Regarding lectures, learning may serve as formative feedback to change the course or teaching/evaluation strategy.

The results of this investigation demonstrate that classroom response systems had a positive impact on self-assessment through continuous appraisal of areas of strength and weakness, since students ranked it as the most significant advantage. Self-assessment is defined as a formative assessment in which the learner can assist their learning and the nature of work, and recognize and appraise the quality and shortcomings of their own learning. ${ }^{28,29}$ In enabling the learners to evaluate their own degree and quality of learning, confidence, self-regulation, motivation, and independence are reinforced. ${ }^{26-30}$ This student-centered strategy may improve in-depth learning through inductive teaching and inspire students to build their own knowledge base. If students are trained to use it as a self-assessment rather than selfgrading, it will be a valuable tool..$^{31,32}$

${ }^{26}$ Rachel Jug, Xiaoyin "Sara” Jiang, and Sarah M. Bean, "Giving and Receiving Effective Feedback: A Review Article and How-to Guide," Archives of Pathology \& Laboratory Medicine 143, no. 2 (2019): 244-250.

${ }^{27}$ Md. Mamoon Al-Bashir, Md. Rezaul Kabir, and Ismat Rahman, "The Value and Effectiveness of Feedback in Improving Students' Learning and Professionalizing Teaching in Higher Education," Journal of Education and Practice 7, no. 16 (2016): 38-41.

${ }^{28}$ Heidi Andrade and Ying Du, "Student Responses to Criteria-Referenced SelfAssessment," Assessment \& Evaluation in Higher Education 32, no. 2 (2007): 159-181, doi:10.1080/02602930600801928.

${ }^{29}$ Abdul Muth'im, "Does Student Self-Assessment Assess as Valid and Reliable as Teacher Assessment?” Arab World English Journal 7, no. 1 (2016): 123-139, doi:10.24093/ awej/vol7no1.9.

${ }^{30}$ Xiaohua He and Anne Canty. "A Comparison of the Efficacy of Test-Driven Learning Versus Self-Assessment Learning," Journal of Chiropractic Education 27, no. 2 (2013): 110115, doi:10.7899/jce-13-6.

${ }^{31}$ Rachel Jug, Xiaoyin "Sara” Jiang, and Sarah M. Bean, "Giving and Receiving Effective Feedback: A Review Article and How-to Guide," Archives of Pathology \& Laboratory Medicine 143, no. 2 (2019): 244-250.

${ }^{32}$ Md. Mamoon Al-Bashir, Md. Rezaul Kabir, and Ismat Rahman, "The Value and Effectiveness of Feedback in Improving Students' Learning and Professionalizing Teaching in Higher Education," Journal of Education and Practice 7, no. 16 (2016): 38-41. 
As reported in the literature, our results indicated that classroom response systems (clickers), may increase students' abilities to solve problems and think, thus better preparing them for their future careers. This method of learning sharpens students' skills and increases their confidence to professionally argue and debate within a scientific context, helps students and educators assess points of strength and weakness both among students and in the course, and deepens the understanding and application of knowledge rather than operating at the lower levels of Bloom's taxonomy.

Although this study provided evidence about the role of classroom response systems in learning, the small sample of students may limit a concrete recommendation. On the other hand, this study outlined several effects of clickers: essentially the positive effect on self-assessment and the boosting of learners' thinking and analysis. In addition, this study provides a direction for future research. Further analysis to investigate and relate this strategy to, for example, other teaching strategies, would contribute to cognitive learning styles and self-efficacy, and should prove to be worthwhile.

\section{Conclusion}

The result of this investigation on using clickers with problem-solving strategies was a positive learning experience, particularly in terms of developing critical thinking, peer discussion, and self-assessment. It can be concluded that aiding problem-solving with the use of clickers can improve students' learning and skills. Certain limitations of the findings within this study need to be acknowledged. First, it was carried out on a small sample. Second, because of a lack of accessibility and student time convenience, a qualitative study was not undertaken. A potential future research direction could also consider using different strategies and different clinical situations and questioning or comparing these. Qualitative studies may further the understanding of student perspectives and the influences of clickers on learners. Limitations aside, the findings may be of value to educators and researchers.

\section{Bibliography}

Al-Bashir, Md. Mamoon, Md. Rezaul Kabir, and Ismat Rahman. "The Value and Effectiveness of Feedback in Improving Students' Learning and Professionalizing Teaching in Higher Education." Journal of Education and Practice 7, no. 16 (2016): 38-41. 
Andrade, Heidi, and Ying Du. "Student Responses to Criteria-Referenced SelfAssessment." Assessment \& Evaluation in Higher Education 32, no. 2 (2007): 159-181. doi:10.1080/02602930600801928.

Brady, Melanie, Helena Seli, and Jane Rosenthal. "“Clickers' and Metacognition: A Quasi-Experimental Comparative Study about Metacognitive Self-Regulation and Use of Electronic Feedback Devices." Computers \& Education 65 (2013): 56-63. https://doi.org/10.1016/j.compedu.2013.02.001.

Buil, Isabel, Sara Catalán, and Eva Martínez. "Do Clickers Enhance Learning? A Control-Value Theory Approach." Computers \& Education 103 (2016): 170182. https://doi.org/10.1016/j.compedu.2016.10.009.

Cakiroglu, Unal, Fath Erdogdu, and Seyfullah Gokoglu. "Clickers in EFL Classrooms: Evidence from Two Different Uses." Contemporary Educational Technology 9, no. 2 (2018): 171-185. https://doi.org/10.30935/cet.414820.

Chen, Wentao, Jinyu Zhang, and Zhonggen Yu. "Advantages and Disadvantages of Clicker Use in Education." International Journal of Information and Communication Technology Education 13, no. 1 (2017): 61-71. https://doi. org/10.4018/ijicte.2017010106.

Coderre, Sylvain P., Peter Harasym, Henry Mandin, and Gordon Fick. "The Impact of Two Multiple-Choice Question Formats on the Problem-Solving Strategies Used by Novices and Experts." BMC Medical Education 4, no. 1 (2004): 23. https://doi.org/10.1186/1472-6920-4-23.

Cook, Rifka, and Susanna Calkins. "More Than Recall and Opinion: Using 'Clickers' to Promote Complex Thinking." Journal on Excellence in College Teaching 24, no. 2 (2019): 51-76.

Deal, Ashley. "Classroom Response Systems.” Published November 30, 2007. https://www.cmu.edu/teaching/technology/whitepapers/ClassroomResponse_ Nov07.pdf. Accessed August 4, 2019.

Demikhova, Nadiia, Prykhodko Olga, Loboda Andrii, Bumeister Valentina, Smiianov Vladyslav, Smiianov Yevgen, Lukianykhin Vadym, and Demikhov Oleksii. "Using PBL and Interactive Methods in Teaching Subjects in Medical Education." Journal of Problem Based Learning in Higher Education 4, no. 1 (2016): 81-90. https://doi.org/10.5278/ojs.jpblhe.v0i0.1227.

Foronda, Cynthia, Brent MacWilliams, and Erin McArthur. "Interprofessional Communication in Healthcare: An Integrative Review." Nurse Education in Practice 19 (2016): 36-40. https://doi.org/10.1016/j.nepr.2016.04.005.

Han, Jae Hoon, and Adam Finkelstein. 'Understanding the Effects of Professors' Pedagogical Development with Clicker Assessment and Feedback Technologies and the Impact on Students' Engagement and Learning in Higher Education." Computers \& Education 65 (2013): 64-76. https://doi.org/10.1016/j. compedu.2013.02.002.

He, Xiaohua, and Anne Canty. "A Comparison of The Efficacy of Test-Driven Learning Versus Self-Assessment Learning.” Journal of Chiropractic Education 27, no. 2 (2013): 110-115. doi:10.7899/jce-13-6. 
Jessup, Leonard M., Terry Connolly, and Jolene Galegher. 1990. "The Effects of Anonymity on GDSS Group Process with an Idea-Generating Task." MIS Quarterly 14 (3): 313-21. doi: 10.2307/248893.

Ju, Hyunjung, and Ikseon Choi. "The Role of Argumentation in HypotheticoDeductive Reasoning During Problem-Based Learning in Medical Education: A Conceptual Framework." Interdisciplinary Journal of Problem-Based Learning 12, no. 1 (2018): 4. https://doi.org/10.7771/1541-5015.1638.

Jug, Rachel, Xiaoyin "Sara" Jiang, and Sarah M. Bean. "Giving and Receiving Effective Feedback: A Review Article and How-to Guide." Archives of Pathology \& Laboratory Medicine 143, no. 2 (2019): 244-250. https://doi. org/10.5858/arpa.2018-0058-ra.

Lantz, Michael E., and Angela Stawiski. "Effectiveness of Clickers: Effect of Feedback and the Timing of Questions on Learning." Computers in Human Behavior 31 (2014): 280-286. https://doi.org/10.1016/j.chb.2013.10.009.

Levesque, Aime A. "Using Clickers to Facilitate Development of Problem-Solving Skills." CBE-Life Sciences Education 10, no. 4 (2011): 406-417. https://doi. org/10.1187/cbe.11-03-0024.

Liu, Cui, Sufen Chen, Chi Chi, Kuei-Pin Chien, Yuzhen Liu, and Te-Lien Chou. "The Effects of Clickers with Different Teaching Strategies." Journal of Educational Computing Research 55, no. 5 (2017): 603-628. https://doi. org/10.1177/0735633116674213.

Meedzan, Nancy, and Kelly L. Fisher. "Clickers in Nursing Education: An Active Learning Tool in the Classroom." Online Journal of Nursing Informatics (OJNI) 13, no. 2 (2019): 1-19.

Millor, Maite, Jon Etxano, Pedro Slon, Paula García-Barquín, Alberto Villanueva, Gorka Bastarrika, and Jesús Ciro Pueyo. "Use of Remote Response Devices: An Effective Interactive Method in the Long-Term Learning." European Radiology 25, no. 3 (2015): 894-900. https://doi.org/10.1007/s00330-014-3468-3.

Morales, Lucia. "Can the Use of Clickers or Continuous Assessment Motivate Critical Thinking? A Case Study Based on Corporate Finance Students." Higher Learning Research Communications 1, no. 1 (2011): 33.https://doi.org/10.18870/ hlrc.v1i1.31.

Muth'im, Abdul. "Does Student Self-Assessment Assess as Valid and Reliable as Teacher Assessment?" Arab World English Journal 7, no. 1 (2016): 123-139. doi:10.24093/awej/vol7no1.9.

Prince, Michael J., and Richard M. Felder. "Inductive Teaching and Learning Methods: Definitions, Comparisons, and Research Bases." Journal of Engineering Education 95, no. 2 (2006): 123-138. https://doi. org/10.1002/j.2168-9830.2006.tb00884.x.

Russell, Janet S., Mindy McWilliams, Laura Chasen, and Jean Farley. "Using Clickers for Clinical Reasoning and Problem Solving." Nurse Educator 36, no. 1 (2011): 13-15. https://doi.org/10.1097/nne.0b013e3182001e18.

Smith, Michelle K., Seanna L. Annis, Jennifer J. Kaplan, and Frank Drummond. "Using Peer Discussion Facilitated by Clicker Questions in an Informal 
Education Setting: Enhancing Farmer Learning of Science." PLOS ONE 7, no. 10 (2012): e47564. https://doi.org/10.1371/journal.pone.0047564.

Smith, Michelle K., William B. Wood, Wendy K. Adams, Carl Wieman, Jennifer K. Knight, Nancy Guild, and Tin Tin Su. "Why Peer Discussion Improves Student Performance on in-Class Concept Questions." Science 323, no. 5910 (2009): 122-124. https://doi.org/10.1126/science.1165919.

Spinello, Elio F., and Ronald Fischbach. "Using a Web-Based Simulation as a Problem-Based Learning Experience: Perceived and Actual Performance of Undergraduate Public Health Students." Public Health Reports 123, no. 2 (2008): 78-84. https://doi.org/10.1177/00333549081230s211.

Stevens, Niall T., Hélène McDermott, Fiona Boland, Teresa Pawlikowska, and Hilary Humphreys. "A Comparative Study: Do 'Clickers' Increase Student Engagement in Multidisciplinary Clinical Microbiology Teaching?" BMC Medical Education 17, no. 1 (2017): 70. https://doi.org/10.1186/s12909-0170906-3.

Wagner, Janet, Beth Liston, and Jackie Miller. "Developing Interprofessional Communication Skills." Teaching and Learning in Nursing 6, no. 3 (2011): 97-101. https://doi.org/10.1016/j.teln.2010.12.003.

\section{About the authors}

HAIFA FAHAD BIN MUBAYRIK (halmobeeriek@ksu.edu.sa), MSc., PhD, is associate professor at Department of Educational policies, College of Education, King Saud University, Riyadh. Saudi Arabia. Has a postgraduate diploma in Education, Master in Adult Education and PhD. in Foundation of Education. Obtained all academic degrees from King Saud university, where she has been since receiving his Ph.D. Have taught in several universities in Saudi before obtaining the PhD: Princess Nora University, King Saud bin Abdulaziz University for Health Sciences and King Saud University. Preformed many researches and supervised many thesis in adult education and continuing education and distance learning. She is the author of several education-related papers on education in both English and native language. Attended and participated in different educational symposiums. Attended many educational workshops in both Saudi and USA on faculty development, active learning and quality control. She was appointed as the head of several committees such as quality control committee. 


\title{
Investigating the effect of clicker use on problem-solving among adult learners: A cross-sectional survey
}

\author{
Haifa Fahad Bin Mubayrik
}

doi: http://dx.doi.org/10.18543/tjhe-7(2)-2020pp141-158

\section{Copyright}

Copyright for this article is retained by the Publisher. It is an Open Access material that is free for full online access, download, storage, distribution, and or reuse in any medium only for noncommercial purposes and in compliance with any applicable copyright legislation, without prior permission from the Publisher or the author(s). In any case, proper acknowledgement of the original publication source must be made and any changes to the original work must be indicated clearly and in a manner that does not suggest the author's and or Publisher's endorsement whatsoever. Any other use of its content in any medium or format, now known or developed in the future, requires prior written permission of the copyright holder. 